\title{
ChemComm
}

Check for updates

Cite this: Chem. Commun., 2020, 56, 13792

Received 3rd August 2020,

Accepted 9th October 2020

DOI: $10.1039 / d 0 c c 05292 b$

rsc.li/chemcomm

\section{Photo-dissociation of self-assembled (anthracene-2-carbonyl)amino acid hydrogels $\dagger$}

\author{
Phillip R. A. Chivers, (D) ${ }^{\text {ab }}$ Rebecca S. Dookie, (D) ${ }^{c}$ Julie E. Gough (D) ${ }^{d}$ and \\ Simon J. Webb (D)*ab
}

\begin{abstract}
Amino acids modified with an $\mathrm{N}$-terminal anthracene group selfassemble into supramolecular hydrogels upon the addition of a range of salts or cell culture medium. Gel-phase photo-dimerisation of gelators results in hydrogel disassembly and was used to recover cells from 3D culture.
\end{abstract}

Hydrogels are an important class of soft material which have found utility in a range of applications. Hydrogels formed by the self-assembly of small molecules, known as supramolecular gels, have grown in interest in recent years. ${ }^{1}$ The synthetic accessibility and stimulus-responsiveness of supramolecular gels makes them attractive candidates for applications ranging from environmental remediation and reaction engineering to tissue engineering and drug formulation. ${ }^{2}$ Supramolecular hydrogels formed by short peptides protected at the $\mathrm{N}$-terminus are particularly attractive, as functional materials with varied chemical, nanotopographical and mechanical properties can be accessed through exploration of peptide sequence space. ${ }^{3}$ The incorporation of unnatural amino acids $^{4}$ and the co-assembly of multiple peptide gelators ${ }^{5}$ can further broaden the range of accessible materials properties.

Increasingly, the importance of spatiotemporal control over the formation or disassembly of supramolecular gels is being recognised. ${ }^{2 a, 6}$ The application of light, ${ }^{7}$ electric potential, ${ }^{8}$ and enzymatic catalysis ${ }^{9}$ have all been used to control the hydrogelation of short peptides. More recently, dynamic systems using the transient transformation of self-assembled structures formed by short peptides have been reported. ${ }^{10,11}$ Instead of

\footnotetext{
${ }^{a}$ Department of Chemistry, University of Manchester, Oxford Road, Manchester, M13 9PL, UK. E-mail: S.Webb@manchester.ac.uk

${ }^{b}$ Manchester Institute of Biotechnology, University of Manchester, 131 Princess St, Manchester, M1 7DN, UK

${ }^{c}$ Manchester Collaborative Centre for Inflammation Research, University of Manchester, 2 Grafton Street, Manchester, M13 9NT, UK

${ }^{d}$ Department of Materials, University of Manchester, MSS Tower, Manchester, M13 9PL, UK

$\dagger$ Electronic supplementary information (ESI) available: Synthesis and cell culture procedures, NMR and fluorescence spectra, rheological data, SEM images. See DOI: $10.1039 / \mathrm{d} 0 \mathrm{cc} 05292 \mathrm{~b}$
}

modifying the local pH or the gelator core, ligating a stimulusresponsive aromatic group to a peptide terminus can also give responsive gels, ${ }^{12}$ e.g. borono- or nitro-phenyl groups can endow redox-responsiveness. ${ }^{13,14}$ Light responsive peptide gels are particularly versatile, with photoirradiation shown to either weaken (e.g. azobenzene termini) or strengthen (e.g. coumarin termini) peptide gels. ${ }^{15}$

We aim to utilise the photo-dimerisation of anthracene (Anth) to develop simple light-responsive peptide hydrogels for biological applications. A bis(gluconamide)-anthracene hydrogel dissociated upon photo-dimerisation, ${ }^{16}$ whereas PEG-based hydrogels stiffen upon photo-dimerisation of anthracene-terminated polymer chains. ${ }^{17}$ Much like the latter example, the photo-dimerisation of coumarin-terminated peptides is reported to produce stiffening of the supramolecular hydrogels. ${ }^{15 b}$ Supramolecular hydrogels formed from anthracene-terminated peptides have interesting electron and energy transfer properties, ${ }^{18 a, b}$ and are reported to combine biocompatibility with antibacterial activity. ${ }^{18 c, d}$ How photoirradiation changes the materials properties of these gels is unreported, however, despite potential applications in controlled drug release, cell culture or tissue engineering.

It was hoped that the simplest anthracene-peptides, those with a single residue, would have the right balance between hydrophobicity and hydrophilicity to self-assemble into fibres. The solution-phase coupling of anthracene-2-carboxylic acid with the respective amino acid methyl esters (see ESI $\dagger$ ) followed by hydrolysis gave the gelators. Although most of these did not form gels (e.g. (Anth)Trp-OH, (Anth)Ala-OH, as well as isomeric anthracene-9-carbonyl derivatives, see $\mathrm{ESI} \dagger$ ), two showed their potential during workup. Slow evaporation of the basic THF: $\mathrm{H}_{2} \mathrm{O}$ solvent used during ester hydrolysis led to in situ hydrogelation of the lithium salts of (Anth)Phe-OH and (Anth)Tyr-OH (Fig. 1).

Of reported gelation triggers, ${ }^{19}$ we focused on salt-triggered gelation to maximise biocompatibility (ESI, $\dagger$ Tables S2 and S3). Basic solutions of (Anth)Phe-OH and (Anth)Tyr-OH gave transparent self-supporting gel-like materials on the addition of 


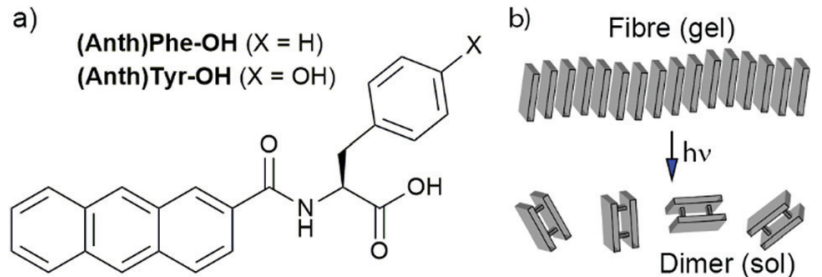

Fig. 1 (a) Structures of the anthracene-amino acid hydrogelators (b) Scheme showing proposed photodimerisation of self-assembled anthracene-amino acids.

$\mathrm{NH}_{4}^{+}, \mathrm{Na}^{+}$and $\mathrm{K}^{+}$salts, whereas adding $\mathrm{M}^{2+}$ or $\mathrm{M}^{3+}$ salts typically gave precipitates. Higher concentrations of both salt and gelator increased the "gelation" rate, which was faster and occurred at lower concentrations for hydrophobic (Anth) Phe-OH compared to (Anth)Tyr-OH. ${ }^{20}$ Metal salt addition gave gel-like materials with a high final $\mathrm{pH}(c a .11),{ }^{21}$ but adding glycinamide $\left(\mathrm{GlyNH}_{2} \cdot \mathrm{HCl}\right.$, Fig. 2a, trigger $\left.\mathbf{A}\right)$ and glucosamine (GlcN.HCl, Table S2, ESI $\dagger$ ) gave more physiologically relevant final $\mathrm{pH}$ values.

Forming hydrogels in cell culture media has been reported to increase biocompatibility. ${ }^{22}$ (Anth)Phe-OH and (Anth)Tyr-OH were insoluble in media at $13 \mathrm{mM}$, but dissolution in basic $\mathrm{H}_{2} \mathrm{O}$ (at $27 \mathrm{mM}$ ) prior to addition of an equal volume of media resulted in rapid gelation of (Anth)Phe-OH (trigger B, Fig. 2a) and slower gelation of (Anth)Tyr-OH. The final $\mathrm{pH}$ for both gels was $c a$. 11, but adding GlcN.HCl (2 eq.) to the media (trigger $\mathbf{C}$, Fig. 2a) lowered the final $\mathrm{pH}$ closer to neutral, as reflected by the colour of the phenol red indicator in the media.

Given our interest in cell encapsulation, standard hydrogels ( $5 \mathrm{mg} \mathrm{mL}^{-1}$ gelator, $13.6 \mathrm{mM}$, triggers $\mathbf{A}, \mathbf{B}$ or $\mathbf{C}$ ) of more rapidly gelling (Anth)Phe-OH were studied further. NMR spectroscopy indicated that $c a .95 \%$ of the (Anth)Phe-OH was mobile in basic water, perhaps as micelles. ${ }^{23}$ Further broadening and disappearance of the gelator resonances occurred after gelation, with

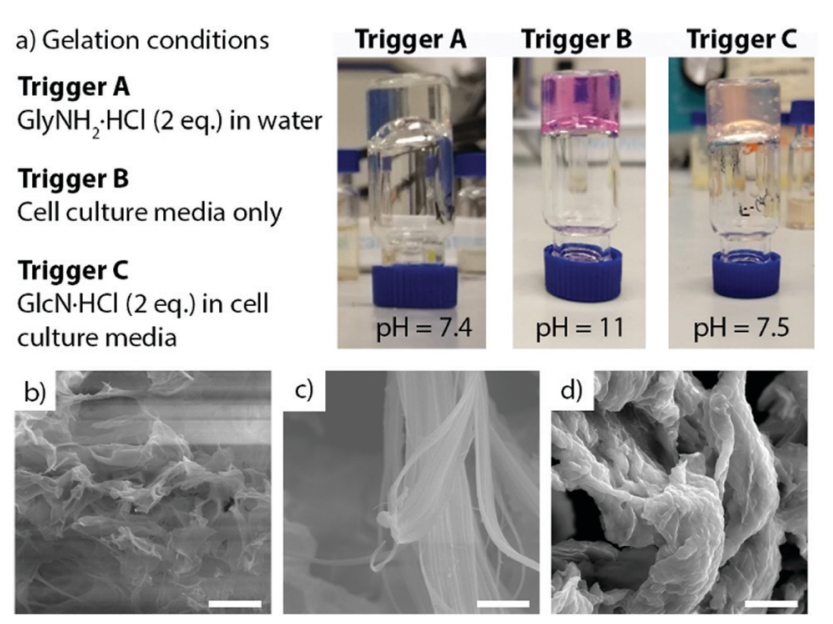

Fig. 2 (a) Images of (Anth)Phe- $\mathrm{OH}$ hydrogels formed after addition of: trigger $\mathbf{A}$ (2 eq. GlyNH$H_{2} \cdot \mathrm{HCl}$ ); trigger $\mathbf{B}$ (cell culture medium); trigger $\mathbf{C}$ (cell culture medium treated 2 eq. GlcN.HCl). The latter two samples have $\mathrm{pH}$ indicator. (b-d) Scanning electron micrographs of gels formed by addition of triggers (b) A, (c) B, (d) C. SEM scale bars $=10 \mu \mathrm{m}$. a)
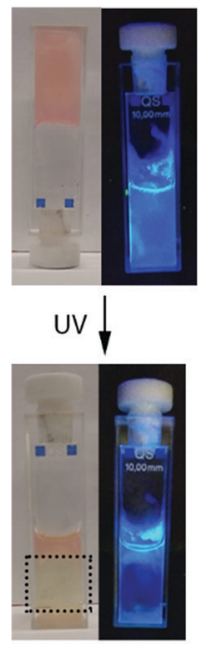

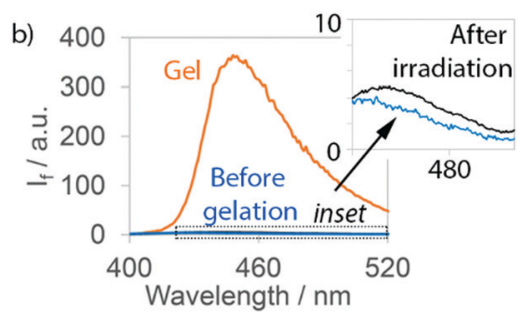

c)

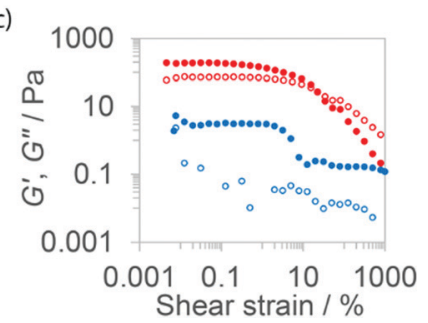

Fig. 3 Data for (Anth)Phe-OH gels formed by trigger $\mathrm{C}$ ( $\mathrm{GlcN} \cdot \mathrm{HCl}$ in media). (a) Optical and fluorescence images of gels before and after irradiation (UV), irradiated region within dotted box; (b) fluorescence spectra of samples before gelation (blue), as a gel (orange) and after irradiation (black); (c) gel rheology traces before (red) and after (blue) irradiation. Filled circles: elastic modulus, $\left(G^{\prime}\right)$. Hollow circles: loss modulus $\left(G^{\prime \prime}\right)$.

integration of the spectra indicating $c a .65 \%$ immobilisation in gel nanofibres (see ESI $\dagger$ ). Gel aging studies showed air and light produced colour changes after several days, which was ascribed to anthraquinone formation (see ESI, $\uparrow$ Section S6). Therefore all gels were freshly prepared before use.

Fluorescence spectroscopy $\left(\lambda_{\text {ex. }}=272 \mathrm{~nm}\right)$ showed enhanced emission at $445 \mathrm{~nm}$ after adding $\mathrm{GlcN} \cdot \mathrm{HCl}$ in media (trigger $\mathrm{C}$, Fig. 3 b) or $\mathrm{GlyNH}_{2} \cdot \mathrm{HCl}$ (trigger A, Fig. S76, ESI $\dagger$ ), consistent with reports of aggregation-induced emission from anthracenecontaining species. ${ }^{18 b, c}$ During gelation using trigger $\mathbf{A}$, the emission intensity increased initially before decreasing (Fig. S92, ESI $\dagger$ ). Gelation using trigger $\mathbf{C}$ also gave a rapid increase in emission intensity followed by a slower decline to a steady state. A self-supporting gel was not evident until this later phase, consistent with nanofibre self-assembly preceding the entanglement necessary for solvent entrapment. ${ }^{24}$

Scanning electron microscopy (SEM) images of lyophilized gels (Fig. 2b-d and Fig. S77, ESI $\dagger$ ) show sample-spanning networks of fine, disperse fibres after gelation by either $\mathrm{GlyNH}_{2} \cdot \mathrm{HCl}$ (trigger A) or GlcN.HCl (Fig. S77, ESI $\dagger$ ), whereas a denser network of laterally associated nanoribbons forms upon gelation by triggers B or $\mathbf{C}$ (media or media/GlcN.HCl). Although the sizes of these objects will be affected by lyophilisation, ${ }^{3 c}$ media and non-media samples show clear morphological differences.

These observations are consistent with the rheological properties of the materials (see ESI, $\dagger$ Fig. S79-S85, ESI $\dagger$ ). Gel-like materials $\left(5 \mathrm{mg} \mathrm{mL}^{-1}\right)$ formed upon addition of amine salts (2 eq., $27 \mathrm{mM}$ ) but they exhibited very low elastic moduli $\left(G^{\prime}\right.$ ca. 4-10 Pa) and liquid-like behaviour. Higher amine salt concentrations (6 eq.) increased the stiffness $\left(G^{\prime} c a .70 \mathrm{~Pa}\right)$ and the materials were more gel-like. Triggers $\mathbf{B}$ and $\mathbf{C}$ formed gels 
that were significantly stiffer $\left(G^{\prime} c a .0 .2 \mathrm{kPa}\right)$ and more comparable to (Fmoc)Phe-OH/(Fmoc)Tyr-OH gels $\left(G^{\prime} 0.25\right.$ to $\left.1 \mathrm{kPa}\right){ }^{25}$ The rheological data for these hydrogels are broadly similar irrespective of the presence of $\mathrm{GlcN} \cdot \mathrm{HCl}$, suggesting that ions in the media, particularly calcium,${ }^{26}$ may determine the nanostructures formed and resulting material properties. The rheological findings are also broadly in line with the observed gel melting temperatures $\left(T_{\text {gel }}\right)$, which increase as either the gelator or salt concentration rises (Table S6, ESI $\dagger$ ).

When in close proximity and on exposure to $365 \mathrm{~nm}$ light, anthracene can dimerise via a [4+4] cycloaddition. ${ }^{27}$ Since fluorescence spectroscopy had indicated the anthracene groups were stacked, these (Anth)Phe-OH gels may be preorganised for photodimerisation. Standard (Anth)Phe-OH gels (trigger C) were formed in fluorescence cuvettes and irradiated with a $365 \mathrm{~nm}$ LED. Irradiated regions quickly became yellow, with strongly reduced fluorescence emission (Fig. 3a and Fig. S76, ESI $\dagger$ ). The gel-to-sol transition in irradiated regions appeared complete after $c a .15 \mathrm{~min}$, whilst areas not directly irradiated remained in the gel state. Even after $1 \mathrm{~h}$ irradiation, the temperatures reached $\left(\leq 41{ }^{\circ} \mathrm{C}\right.$, Table $\left.\mathrm{S} 7, \mathrm{ESI} \dagger\right)$ were much lower than the respective $T_{\text {gel }}$ values $\left(>100{ }^{\circ} \mathrm{C}\right.$, see $\left.\mathrm{ESI} \dagger\right)$, confirming that disassembly was due to chemical changes rather than heating.

To characterise the disassembly process, regions that had been irradiated for $1 \mathrm{~h}$ were isolated from remaining gel. Fluorescence spectroscopy showed the irradiated regions exhibited almost no emission, much like the pre-gelation peptides (Fig. 3b for trigger C, Fig. S76, ESI, $\dagger$ for trigger A). SEM showed small assemblies in irradiated samples, but no evidence of sample-spanning networks (Fig. S78, ESI $\dagger$ ). Together with a significant decrease in elastic modulus after UV-exposure (Fig. 3c and Fig. S76, ESI $\dagger$ ), this suggested near total nanofibre disassembly for hydrogels formed by triggers $\mathbf{A}$ and $\mathbf{C}$.

Mass spectrometry and ${ }^{1} \mathrm{H}$ NMR spectroscopy confirmed that gelator dimerization had occurred in the gels. The former showed molecular ion peaks for dimer at $737.3 \mathrm{~m} / \mathrm{z}\left([\mathrm{M}+\mathrm{H}]^{+}\right)$. The latter revealed resonances at $4.7 \mathrm{ppm}$ that are characteristic of bridgehead protons in (Anth)Phe-OH dimers (see the ESI $\dagger$ ), whilst resonances from the monomer 9- and 10-aromatic protons were significantly reduced in intensity. Conversions to the dimer in gels triggered by $\mathbf{C}$ and $\mathbf{A}$ ( $63 \%$ and $81 \%$ respectively) are comparable to reported values for anthracene-gluconamide hydrogels. ${ }^{16}$

The cycloaddition of 2-substituted anthracenes can produce four regioisomers, the distribution of which can report on anthracene orientation in gel fibres. ${ }^{16,28}$ New amide-NH/Phe-CH cross coupling peaks in the COSY NMR spectra of irradiated samples (e.g. Fig. S69, ESI $\dagger$ ), suggested at least three cycloaddition products could form. Photoirradiated gel and solution samples showed differences in the shape of the overlapping bridgehead and vicinal aromatic (7.4 ppm) proton resonances (e.g. Fig. S37 and S68, ESI $\dagger$ ), but even at $800 \mathrm{MHz}$ these peaks were insufficiently resolved to provide an isomer distribution (Fig. S38, ESI $\dagger$ ). HPLC of anthracene-2-carboxylic acid dimers formed in ordered media has allowed regioisomer distribution to be quantified, ${ }^{29}$ but HPLC separation of (Anth)Phe-OH dimers could not be achieved.
The potential of (Anth)Phe-OH gels triggered by $\mathbf{C}$ ( GlcN. $\mathrm{HCl}$ in media) for the encapsulation, growth and recovery of cells was then assessed. Standard hydrogels $(50 \mu \mathrm{L})$ were prepared in hanging cell culture inserts and submerged in 24 well plates filled with media (1.5 mL). Suspension of either NIH/3T3 fibroblasts or human-derived chondrocytes in the media prior to mixing with gelator solution gave $3 \mathrm{D}$ cultures $\left(1 \times 10^{6}\right.$ cells $\left.\mathrm{mL}^{-1}\right)$ in the (Anth)Phe-OH hydrogels. Cell culture in $3 \mathrm{D}$ better mimics in vivo conditions, and for many cell types - including chondrocytes improves phenotypic regulation compared to monolayer growth. ${ }^{30}$ A 2D control was also performed, with culture on the gel surface $\left(2 \times 10^{5}\right.$ cells $\left.\mathrm{mL}^{-1}\right)$. Culture on tissue culture plastic $\left(2 \times 10^{5}\right.$ cells $\left.\mathrm{mL}^{-1}\right)$ provided a further control.

Light microscopy showed no adhesion and spreading by cells cultured in or on (Anth)Phe-OH hydrogels after $2 \mathrm{~h}$, in contrast to cells grown on tissue culture plastic. After $72 \mathrm{~h}$, gels had large cell agglomerates consistent with cell death (Fig. 4a, right). Visualisation of LIVE/DEAD 3T3 cells and chondrocytes by confocal microscopy indicated that most cells in these samples were dead (ESI, $\dagger$ Fig. S96 and S97), but co-staining of the gel by ethidium homodimer prevented quantification. To overcome this problem, light-mediated disassembly of the (Anth)Phe-OH hydrogels was used to release the cells prior to staining. Irradiation with $365 \mathrm{~nm}$ light for 5 min resulted in complete gel degradation. Purification of the cells by repeated washing and centrifugation cycles yielded samples suitable for flow cytometry. This confirmed that even after $2 \mathrm{~h},>90 \%$ of the $3 \mathrm{~T} 3$ cells and chondrocytes in 3D culture were dead or undergoing necrosis (Fig. 4b and Fig. S103, ESI $\dagger$ ); the proportion of dead cells increased after $72 \mathrm{~h}$. Similar levels of cell death were also found when cells were seeded on top of a pre-formed hydrogel.

Low cell viability is not thought to be due to sample handling or the gel fabrication methodology. Control samples cultured on tissue culture plastic showed high survival even after a UV exposure regime identical to that used with $3 \mathrm{D}$ culture. However, media containing GlcN.HCl induced significant cell death over $72 \mathrm{~h}$ (Fig. S100 and S102, ESI $\dagger$ ) despite the reported tolerance of chondrocytes to GlcN $(<5 \mathrm{mM}) \cdot{ }^{31}$ Cell survival was strongly diminished by suspension of (Anth) Phe-OH hydrogels above cell monolayers, which suggests that
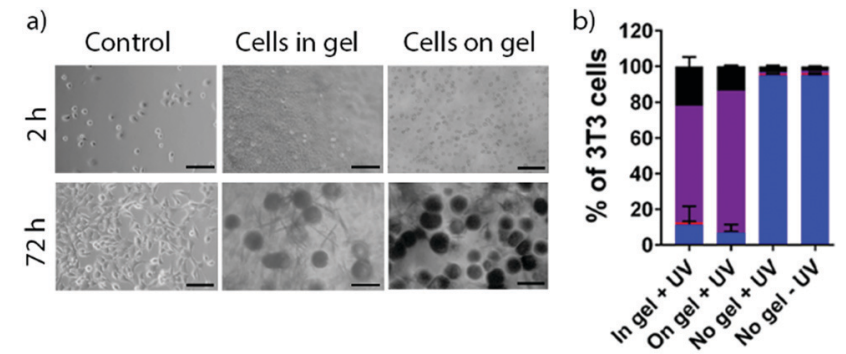

Fig. 4 (a) Light microscopy images at $2 \mathrm{~h}$ and $72 \mathrm{~h}$ of $\mathrm{NIH} / 3 \mathrm{~T} 3$ fibroblasts cultured in contact with (Anth)Phe-OH hydrogels (trigger $\mathrm{C}$ ) in $2 \mathrm{D}$ or $3 \mathrm{D}$ culture. Cells grown on tissue culture plastic shown as control samples. Scale bars $=32 \mu \mathrm{m}$. (b) Flow cytometric data after 2 h. ( $\square$ ) Live; ( $\square$ ) early apoptotic; ( $\mathbf{\square})$ late apoptotic/necrotic; ( $\mathbf{\square})$ dead. 
significant amounts of GlcN.HCl and/or gelator can leach out of the gels. These gels may also be too soft for fibroblasts and chondrocytes, which proliferate more readily on stiff gels. ${ }^{32}$ We suggest that a combination of component cytotoxicity, gel softness, and weak adhesion to the hydrophobic nanofibres accounts for poor survival of the studied cell types.

In summary, we have developed anthracene-amino acid hydrogels and found they undergo controlled disassembly when exposed to long-wave UV light. This behaviour is noteworthy for such readily accessible and structurally simple gelators. ${ }^{15 a}$ The properties of these hydrogels could be tuned by varying the structure and concentration of both the gelator and trigger. The photo-induced gel-phase dimerisation of anthracene headgroups resulted in gel degradation, and was used to release encapsulated cells for standard biochemical analysis. The amino acid core in these gelator provides flexibility for future developments, e.g. exploiting peptide sequence space to obtain gelators able to form stiffer gels with greater suitability for cell culture. Similarly, salts with lower toxicity towards different cell types should be used to trigger gelation. Nonetheless the discovery that anthracene-amino acid hydrogels can undergo rapid photodissociation indicates a pathway towards new types of degradable biomaterials for use in regenerative medicine and wound healing applications.

We thank EPSRC for the award of a Doctoral Prize (PRAC), Prof. A. Saiani for rheometer access, Prof. A. MacDonald for access to cell characterisation equipment, Dr T. Starborg for collection of SEM images and Dr L. Carney for cell culture training (PRAC).

\section{Conflicts of interest}

There are no conflicts to declare.

\section{References}

1 R. G. Weiss, J. Am. Chem. Soc., 2014, 136, 7519-7530.

2 (a) P. R. A. Chivers and D. K. Smith, Nat. Rev. Mater., 2019, 4, 463-478; (b) E. R. Draper and D. J. Adams, Chem, 2017, 3, 390-410; (c) H. Wang, Z. Feng and B. Xu, Angew. Chem., Int. Ed., 2019, 58, 10423-10432.

3 (a) W. Y. Seow and C. A. E. Hauser, Mater. Today, 2014, 17, 381-388; (b) S. Mondal, S. Das and A. K. Nandi, Soft Matter, 2020, 16, 1404-1454; (c) L. L. E. Mears, E. R. Draper, A. M. Castilla, H. Su, Zhuola, B. Dietrich, M. C. Nolan, G. N. Smith, J. Doutch, S. Rogers, R. Akhtar, H. Cui and D. J. Adams, Biomacromol., 2017, 18, 3531-3540.

4 (a) R. Orbach, L. Adler-Abramovich, S. Zigerson, I. Mironi-Harpaz, D. Seliktar and E. Gazit, Biomacromol., 2009, 10, 2646-2651; (b) L. McDougall, E. R. Draper, J. D. Beadle, M. Shipman, P. Raubo, A. G. Jamieson and D. J. Adams, Chem. Commun., 2018, 54, 1793-1796.

5 (a) E. R. Draper, E. G. B. Eden, T. O. McDonald and D. J. Adams, Nat. Chem., 2015, 7, 848-852; (b) P. J. S. King, M. G. Lizio, A. Booth, R. F. Collins, J. E. Gough, A. F. Miller and S. J. Webb, Soft Matter, 2016, 12, 1915-1923.

6 (a) P. R. A. Chivers and D. K. Smith, Chem. Sci., 2017, 8, 7218-7227; (b) P. R. A. Chivers, J. A. Kelly, M. J. S. Hill and D. K. Smith, React. Chem. Eng., 2020, 5, 1112-1117.

7 (a) J. Raeburn, T. O. McDonald and D. J. Adams, Chem. Commun., 2012, 48, 9355-9357; (b) X. Li, J. Fei, Y. Xu, D. Li, T. Yuan, G. Li, C. Wang and J. Li, Angew. Chem., Int. Ed., 2018, 57, 1903-1907.
8 J. Raeburn, B. Alston, J. Kroeger, T. O. McDonald, J. R. Howse, P. J. Cameron and D. J. Adams, Mater. Horiz., 2014, 1, 241-246.

9 (a) R. J. Williams, A. M. Smith, R. Collins, N. Hodson, A. K. Das and R. V. Ulijn, Nat. Nanotechnol., 2009, 4, 19-24; (b) J. R. Fores, M. L. Martinez Mendez, X. Mao, D. Wagner, M. Schmutz, M. Rabineau, P. Lavalle, P. Schaaf, F. Boulmedais and L. Jierry, Angew. Chem., Int. Ed., 2017, 56, 15984-15988.

10 (a) S. Panja, B. Dietrich and D. J. Adams, ChemSystemsChem, 2020, 2, e1900038; (b) S. Panja and D. J. Adams, Chem. Commun., 2019, 55, 10154-10157.

11 N. Singh, B. Lainer, G. J. M. Formon, S. De Piccoli and T. M. Hermans, J. Am. Chem. Soc., 2020, 142, 4083-4087.

12 A. D. Martin and P. Thordarson, J. Mater. Chem. B, 2020, 8, 863-877.

13 M. Ikeda, T. Tanida, T. Yoshii, K. Kurotani, S. Onogi, K. Urayama and I. Hamachi, Nat. Chem., 2014, 6, 511-518.

14 H. Shigemitsu, T. Fujisaku, W. Tanaka, R. Kubota, S. Minami, K. Urayama and I. Hamachi, Nat. Nanotechnol., 2018, 13, 165-172.

15 (a) D. Wu, X. Xie, A. A. Kadi and Y. Zhang, Chin. Chem. Lett., 2018, 29, 1098-1104; (b) E. R. Draper, T. O. McDonald and D. J. Adams, Chem. Commun., 2015, 51, 12827-12830.

16 Y. Sako and Y. Takaguchi, Org. Biomol. Chem., 2008, 6, 3843-3847. 17 (a) K. Arda Günay, T. L. Ceccato, J. S. Silver, K. L. Bannister, O. J. Bednarski, L. A. Leinwand and K. S. Anseth, Angew. Chem., Int. Ed., 2019, 58, 9912-9916; (b) V. X. Truong, F. Li and J. S. Forsythe, ACS Macro Lett., 2017, 6, 657-662.

18 (a) L. Chen, S. Revel, K. Morris and D. J. Adams, Chem. Commun., 2010, 46, 4267-4269; (b) S. Biswas, D. B. Rasale and A. K. Das, RSC Adv., 2016, 6, 54793-54800; (c) P. K. Gavel, D. Dev, H. S. Parmar, S. Bhasin and A. K. Das, ACS Appl. Mater. Interfaces, 2018, 10, 10729-10740; (d) P. K. Gavel, H. S. Parmar, V. Tripathi, N. Kumar, A. Biswas and A. K. Das, ACS Appl. Mater. Interfaces, 2019, 11, 2849-2859.

19 S. Awhida, E. R. Draper, T. O. McDonald and D. J. Adams, J. Colloid Interface Sci., 2015, 455, 24-31.

20 A. R. Hirst, I. A. Coates, T. R. Boucheteau, J. F. Miravet, B. Escuder, V. Castelletto, I. W. Hamley and D. K. Smith, J. Am. Chem. Soc., 2008, 130, 9113-9121.

21 K. MacAulay, P. Agís Ucha, H. Wang, A. M. Fuentes-Caparrós, L. Thomson, O. Maklad, N. Khunti, N. Cowieson, M. Wallace, H. Cui, R. J. Poole, A. Seddon and D. J. Adams, Chem. Commun., 2020, 56, 4094-4097.

22 H. McEwen, E. Y. Du, J. P. Mata, P. Thordarson and A. D. Martin, J. Mater. Chem. B, 2017, 5, 9412-9417.

23 E. R. Draper, H. Su, C. Brasnett, R. J. Poole, S. Rogers, H. Cui, A. Seddon and D. J. Adams, Angew. Chem., Int. Ed., 2017, 56, 10467-10470.

24 C. Tang, A. M. Smith, R. F. Collins, R. V. Ulijn and A. Saiani, Langmuir, 2009, 25, 9447-9453.

25 (a) D. M. Ryan, S. B. Anderson, F. T. Senguen, R. E. Youngman and B. L. Nilsson, Soft Matter, 2010, 6, 475-479; (b) Y. Wang, Z. Zhang, L. Xu, X. Li and H. Chen, Colloids Surf., B, 2013, 104, 163-168.

26 L. Chen, G. Pont, K. Morris, G. Lotze, A. Squires, L. C. Serpell and D. J. Adams, Chem. Commun., 2011, 47, 12071-12073.

27 G. W. Breton and X. Vang, J. Chem. Educ., 1998, 75, 81.

28 (a) Y.-C. Lin, B. Kachar and R. G. Weiss, J. Am. Chem. Soc., 1989, 111, 5542-5551; (b) A. Dawn, N. Fujita, S. Haraguchi, K. Sada and S. Shinkai, Chem. Commun., 2009, 2100-2102.

29 (a) Y. Ishida, Y. Matsuoka, Y. Kai, K. Yamada, K. Nakagawa, T. Asahi and K. Saigo, J. Am. Chem. Soc., 2013, 135, 6407-6410; (b) A. Nakamura and Y. Inoue, J. Am. Chem. Soc., 2003, 125, 966-972; (c) Y. Ishida, Y. Kai, S. Kato, A. Misawa, S. Amano, Y. Matsuoka and K. Saigo, Angew. Chem., Int. Ed., 2008, 47, 8241-8245.

30 (a) P. Yeung, K. H. Cheng, C. H. Yan and B. P. Chan, Sci. Rep., 2019, 9, 12453; (b) C. Jensen and Y. Teng, Front. Mol. Biosci., 2020, 7, 33.

31 (a) S. Varghese, P. Theprungsirikul, S. Sahani, N. Hwang, K. J. Yarema and J. H. Elisseef, Osteoarthritis Cartilage, 2007, 15, 59-68; (b) Y. Ma, W. Zheng, H. Chen, X. Shao, P. Lin, X. Liu, X. Li and H. Ye, Int. J. Mol. Med., 2018, 42, 61-70.

32 (a) E. Hadjipanayi, V. Mudera and R. A. Brown, J. Tissue Eng. Regener. Med., 2009, 3, 77-84; (b) V. Jayawarna, S. M. Richardson, A. R. Hirst, N. W. Hodson, A. Saiani, J. E. Gough and R. V. Ulijn, Acta Biomater., 2009, 5, 934-943. 